\title{
Literasi Kitab Kuning pada Santri Pondok Pesantren Al- Muhsinin Desa Koto Petai Kabupaten Kerinci
}

\author{
Dian Maisaroh \\ IIS-Kosentrasi Ilmu Perpustakaan dan Informasi, UIN Sunan Kalijaga Yogyakarta \\ Jl. Laksda Adisucipto, Daerah Istimewa Yogyakarta 55281 \\ e-mail: dianmaisaroh20@gmail.com
}

\begin{abstract}
Introduction. The purpose of this study was to determine the ability of the students of the Al-Muhsinin Islamic Boarding School in Koto Petai Village to access, evaluate, and use information on the kitab kuning content with literacy standards of the International Federation of Library Association and Institutions (IFLA).

Data Collection Method. To collect precise and accurate data, the researcher used qualitative research. The method of determining the subject was done by purposive sampling, the data collection methods used were the interview method, the observation method and the documentation method.

Analysis Data. Data analysis was used, namely data reduction, data presentation, and drawing conclusions.

Results and Discussions. The results of this study are: The ability of the Santri at the AlMuhsinin Islamic Boarding School of the Koto Petai Village in Accessing Information on the Kitab Kuning is quite good, this can be seen from the information obtained from discussions with teachers and clerics and also with friends. and chosen to be applicable in everyday life. The ability of the Santri at the Al-Muhsinin Islamic Boarding School of Koto Petai Village in Evaluating Information on the Kitab Kuning is quite good, it can be seen that to get clear information each person has different versions, some select and sort the information first and some are direct use the information. It depends on each person how to get the information. The ability of the Santri at Al-Muhsinin Koto Petai Islamic Boarding School in using the Kitab Kuning information is not good. It can be seen that in using the information obtained by the informants they have not applied or applied it and in communicating information to other parties, the informants also rarely communicate the information they know to other parties.
\end{abstract}

Keywords: Information Literacy, Kitab Kuning, Santri

\section{ABSTRAK}

Pendahuluan. Tujuan dari penelitian ini yaitu untuk mengetahui bagaimana kemampuan santri Pondok Pesantren Al-Muhsinin Desa Koto Petai dalam mengakses, mengevaluasi, dan menggunakan informasi kandungan kitab kuning dengan standar literasi International Federation of Library Association and Institutions (IFLA). 
Metode penelitian. Untuk mengumpulkan data yang tepat dan akurat, peneliti menggunakan penelitian kualitatif, cara penentuan subjek ini dilakukan dengan cara purposive sampling, metode pengumpulan data yang digunakan yaitu metode wawancara, metode observasi dan metode dokumentasi.

Data analisis. Analisis data digunakan yaitu reduksi data, penyajian data, dan menarik kesimpulan.

Hasil dan Pembahasan. Hasil dari penelitian ini yaitu: Kemampuan Santri Pondok Pesantren Al-Muhsinin Desa Koto Petai dalam Mengakses Informasi Kitab Kuning cukup baik, ini dapat dilihat dari informasi yang didapat dari berdiskusi besama guru dan ustadz dan juga bersama teman-teman selanjutnya informasi yang didapat ini kemudian dipilah dan dipilih untuk bisa diterapkan dalam kehidupan sehari-hari. Kemampuan Santri Pondok Pesantren Al-Muhsinin Desa Koto Petai dalam Mengevaluasi Informasi Kitab Kuning cukup baik, ini dapat dilihat bahwa untuk mendapatkan informasi yang jelas setiap orang mempunyai versi yang bebeda-beda jenisnya, ada yang memilih dan memilah terlebih dahulu informasinya dan ada juga yang langsung menggunakan informasinya. Tergantung dari setiap orang bagaimana cara mendapatkan informasinya. Kemampuan Santri Pondok Pesantren Al-Muhsinin Koto Petai dalam menggunakan informasi kitab kuning kurang baik. Hal ini dapat dilihat bahwa dalam menggunakan informasi yang di peroleh informan belum menerapkan atau mengaplikasikannya dan dalam mengkomunikasikan informasi kepada pihak lain informan juga jarang sekali untuk mengkomunikasikan informasi yang diketahuinya kepada pihak lain.

Kata Kunci: Literasi Informasi, Kitab Kuning, Santri

\section{A. LATAR BELAKANG}

Permasalahan literasi merupakan salah satu permasalahan yang harus mendapatkan perhatian khusus oleh Bangsa Indonesia. Karena masyarakat kita belum menjadikan aktivitas membaca dan menulis sebagai kebiasaan seharihari. Purwanto mengemukakan bahwa hal ini disebabkan oleh masyarakat Indonesia merupakan masyarakat eliterat, artinya masyarakat yang bisa membaca namun, belum memiliki keinginan untuk menjadikan kebiasaan membaca sebagai aktifitas sehari-hari. ${ }^{1}$ Menurut Alberta menjelaskan bahwa literasi bukan hanya sekedar kemampuan untuk membaca dan menulis namun menambah pengetahuan, keterampilan, dan kemampuan yang dapat membuat seseorang memiliki kemampuan berpikir kritis, konteks, mampu berkomunikasi

${ }^{1}$ Kharizmi, M. (2015). Kesulitan siswa sekolah dasar dalam meningkatkan kemampuan literasi. Jupendas. Vol. 2, No. 2. http://jfkip.umuslim.ac.id/index.php/jupendas/article/view/233. (21 agustus 2019). HIm 12. 
secara efektif dan mampu mengembangkan potensi serta berpartisipasi aktif dalam kehidupan bermasyarakat. ${ }^{2}$ Literasi berfungsi untuk menghubungkan individu dan masyarakat, serta merupakan alat penting bagi individu untuk tumbuh dan berpartisipasi aktif dalam masyarakat yang demokratis. ${ }^{3}$ Literasi informasi juga penting bagi masyarakat baik sosial, ekonomi, politik, budaya dan pendidikan. Kegiatan membaca merupakan hal yang sangat penting bagi kemajuan suatu bangsa. Literasi sangat penting untuk mengembangkan pengetahuan terhadap masyarakat agar lebih memahami informasi yang mereka butuhkan. Kabupaten Kerinci, tepatnya di Desa Koto Petai dikenal dengan desa yang agamis, karena pada dahulunya banyak ustadz-ustadz dan ulama-ulama besar yang berkumpul dan mengkaji mengenai kajian-kajian dari kitab-kitab kuning serta kajian mengenai keagamaan. Budaya mengkaji kajian kitab-kitab kuning dan kajian keagamaan inipun terus dilaksanakan hingga sekarang. Desa koto petai merupakan salah satu desa yang di dalamnya terdapat pondok pesantren. Pondok pesantren ini memfokuskan kegiatan ekstra kurikulernya pada bidang keagamaan yakni kegiatan pengkajian kitab kuning yang dilaksanakan setiap malam senin hingga malam kamis. Kitab kuning merupakan istilah yang identik dipelajari khususnya di pondok pesantren, karena kitab kuning ini menjadi rujukan utama dan merupakan ciri khas pembeda antara pondok pesantren dan lembaga-lembaga pendidik islam lainnya. Kitab kuning juga merupakan istilah yang sering digunakan untuk kitab-kitab gundul berbahasa arab yang biasa digunakan di banyak pesantren sebagai bahan pelajaran. kitab kuning bukan hanya merupakan ciri khas yang membedakan dari lembaga pendidik pondok pesantren namun juga dikatakan bahwa pentingnya mempelajari kitab kuning sebagai panduan dalam kehidupan sehari-hari dan juga untuk memahami, menafsirkan, menerapkan hukum positif dari kitab yang dipelajari. Dari penelitian awal yang dilakukan oleh peneliti mengenai santri Pondok Pesantren Al-Muhsinin Koto Petai yang mengkaji kitab kuning dimana

${ }^{2}$ Malawi, I. (2017). Pembelajaran Literasi Berbasis Sastra Lokal. Jawa Timur: Media Grafika. Hlm 8

${ }^{3}$ Abidin, y. (2018). Pembelajaran Literasi. Jakarta: Bumi Aksara. Hlm 1 
pada dasarnya masih ada yang kurang menggunakan dan menerapkan ilmu yang mereka dapat dari mengkaji Kitab kuning dalam kehidupan sehari-hari, serta juga tidak terlihat dampak positif dari perubahan tingkah laku santri Pondok Pesantren Koto Petai setelah mengkaji kitab kuning. Dari hal ini peneliti tertarik untuk meneliti lebih lanjut faktor apa yang menyebabkan santri Pondok Pesantren Koto Petai ini masih ada yang tidak menggunakan atau menerapkan informasi yang mereka dapatkan dari mempelajari kitab kuning padahal mengkaji kitab kuning ini sudah menjadi tradisi atau budaya yang terus dilaksanakan hampir setiap malam di Desa Koto Petai dan juga ini merupakan kegiatan ekstrakurikuler yang wajib dilaksanakan di Pondok Pesantren AlMuhsinin Koto Petai. Berdasarkan uraian di atas peneliti tertarik untuk melakukan penelitian yang berjudul Literasi Kitab Kuning pada Santri Pondok Pesantren Al-Muhsinin Desa Koto Petai Kabupaten Kerinci.

\section{B. TINJAUAN PUSTAKA}

\section{Pengertian Literasi}

Secara Etimologis, literasi berasal dari bahasa latin littera yang memiliki pengertian sistem tulisan yang menyertainya. Literasi adalah hak asasi manusia yang fundamental dan pondasi untuk belajar sepanjang hayat. Hal ini penting sepenuhnya untuk pembangunan sosial dan manusia dalam kemampuannya untuk mengubah kehidupan. ${ }^{4}$ Literasi didefinisikan sebagai kemampuan untuk menggunakan bahasa dan gambar dalam bentuk yang kaya dan beragam untuk membaca, menulis, mendengarkan, berbicara, melihat, menyajikan, dan berpikir kritis tentang ide-ide. Literasi merupakan proses yang melibatkan pembangunan pengetahuan baru dan pemahaman yang lebih dalam. ${ }^{5}$ Menurut American Library Association (ALA) mendefinisikan literasi informasi (Information Literacy) adalah serangkaian kemampuan yang dibutuhkan seseorang untuk menyadari kapan informasi

${ }^{4}$ Malawi, I. (2017). Pembelajaran Literasi Berbasis Sastra Lokal. Jawa Timur: media grafika. Hlm 6

${ }^{5}$ Abidin, Y. (2018). Pembelajaran Literasi. Jakarta: Bumi Aksara. Hlm 1 
dibutuhkan dan memiliki kemampuan untuk menemukan, mengevaluasi, dan menggunakan informasi yang dibutuhkan secara efektif. ${ }^{6}$ Berdasarkan definisi literasi informasi (informasi literacy) dapat disimpulkan bahwa serankaian kemampuan yang dibutuhkan seseorang untuk menyadari kapan informasi dibutuhkan dan memiliki kemampuan untuk mencari, mengevaluasi, menggunakan, dan mengomunikasikan informasi secara efektif. Menurut UNESCO literasi informasi memampukan seseorang untuk menafsirkan informasi sebagai pengguna informasi dan menjadi penghasil informasi bagi dirinya sendiri. Tujuan literasi informasi yaitu untuk mengetahui bagaimana mengorganisasikan informasi, bagaimana menemukan informasi dan memanfaatkan informasi sebagai modal untuk pendidikan seumur hidup. Oleh sebab itu literasi sangat penting bagi masyarakat baik sosial, ekonomi, politik, budaya dan pendidikan. ${ }^{7}$ Tujuan dari pengembangan literasi informasi ini, dapat dikatakan sebagai bentuk usaha meningkatkan kualitas masyarakat penggunannya. Dalam konteks pengembangan manajemen pengetahuan, program literasi informasi ditujukan untuk berbagai hal:

1. Pengembangan pengetahuan.

2. Perekaman dan organisasi pengetahuan

3. Penyebaran informasi

\section{Jenis Kebutuhan Informasi}

Jenis kebutuhan informasi, antara lain adalah:

a. Kebutuhan kognitif, ini berkaitan erat dengan kebutuhan untuk memperkuat informasi, pengetahuan dan pemahaman seseorang akan lingkungannya. Kebutuhan ini didasarkan pada hasrat sesorang untuk memahami dan menguasai lingkungannya. Disamping itu, kebutuhan

\section{2}

${ }^{6}$ Hartono. (2016). Manajemen Perpustakaan Sekolah. Yogyakarta: Ar-Ruzz Media. Hlm

${ }^{7}$ Mentari , A. (2014). Literasi Informasi Politik Pada Masyarakat di Tempat Pemungutan Suara Desa Simpang Sungai Duren Kabupaten Muaro Jambi. Skripsi IAIN sulthan thaha saifuddin Jambi. 
ini juga dapat memberi kepuasan atas hasrat keingintahuan dan penyelidikan seseorang. Kebutuhan efektif. Kebutuhan ini dikaitkan dengan pengetahuan estesis, hal yang dapat menyenangkan, dan pengalaman-pengalaman emosional. Dalam hal ini, berbagai media sering dijadikan alat untuk mengejar kesenangan dan hiburan. Misalnya, orang membeli radio, televisi, dan menonton film, tidak lain karena mencari hiburan.

b. Kebutuhan integritas personal (personal integrative needs). ini dikaitkan dengan penguatan kredibilitas, kepercayaan, stabilitas, dan status individu. Kebutuhan-kebutuhan ini berasal dari hasrat seseorang untuk mencari harga diri.

c. Kebutuhan integrasi sosial (social integrative needs). Kebutuhan ini berkaitan dengan penguatan hubungan keluarga, teman, dan orang lain di dunia. Kebutuhan ini didasari oleh hasrat seseorang untuk bergabung atau berkelompok dengan orang lain.

d. Kebutuhan berkhayal (Escapistneeds). Ini dikaitkan dengan kebutuhankebutuhan untuk melarikan diri, melepaskan ketegangan, dan hasrat mencari hiburan dan pengalihan. ${ }^{8}$

\section{Standar Literasi Informasi IFLA}

Literasi informasi mengarahkan pengetahuan akan kesadaran dan kebutuhan informasi seseorang, dan kemampuan untuk mengidentifikasi, menemukan, mengevaluasi, mengorganisasi secara efektif menciptakan, menggunakan, mengkomunikasikan informasi untuk mencari solusi atas masalah yang dihadapi, juga merupakan persyaratan untuk berpartisipasi dalam masyarakat informasi, dan merupakan Hak Asasi Manusia untuk belajar sepanjang hayat. Menurut IFLA standar Literasi Informasi menjadi

\footnotetext{
8 (katz dikutip oleh yusup, 2009:205)

http://www.researchgate.net/publication/331096122 PERILAKU PENCARI INFORMASI_INF ORMATION_SEEKINGBEHAVIOR GURU_BESAR_IAIN_ANTASARI_BANJARMASIN. (diakses pada tanggal 12 november 2019)
} 
pembelajaran yang efektif meliputi 3 komponen dasar: Akses, Evaluasi dan Penggunaan. ${ }^{9}$

\section{Akses Informasi}

a) Mendefinisikan Kebutuhan Informasi

- Menemukan atau menggali kebutuhan informasi

- Memutuskan suatu tindakan untuk menemukan informasi

- Menyatakan dan menentukan kebutuhan informasi

- Mulai melakukan pencarian informasi

b) Penelusuran Informasi

- Mengidentifikasi dan meng-evaluasi sumber-sumber informasi yang potensial

- Mengembangkan strategi-strategi pencarian informasi

- Mengakses sumber-sumber informasi yang terpilih

- Memilih dan menemukan informasi yang dibutuhkan

\section{Evaluasi Informasi}

a) Penilaian Informasi

- Menganalisis, memeriksa, dan menyaring informasi

- Menggeneralisasikan dan menginterprestasikan informasi

- Memilih dan menggabungkan informasi

- Mengevaluasi keakuratan dan hubungan dari informasi yang ditemukan

b) Pengaturan Informasi

- Menyusun dan mengkategorikan informasi

- Menyatukan dan mengatur informasi

- Menentukan informasi-informasi yang terbaik dan paling berguna untuk digunakan

\section{Penggunaan Informasi}

a) Menggunakan Informasi

${ }^{9}$ Lau, Jesus. Guiddelines on Information Literacy for lifelong Learning. Veracruz: IFLA. 2006. Hlm.16 
- Menemukan cara untuk mengkomunikasikan, menyajikan dan menggunakan informasi

- Mengaplikasikan informasi yang ditemukan

- Mempelajari dan mendalami informasi yang ditemukan untuk menjadi pengetahuan pribadi

- Mempersentasikan hasil motivasi

b) Mengkomunikasikan dan menggunakan informasi secara etis

- Memahami etika penggunaan informasi

- Mematuhi peraturan penggunaan informasi

- Mengkomunikasikan hasil pembelajaran dengan pengetahuan intelektual yang dimiliki

- Menggunakan pengetahuan yang relevan sesuai dengan standar

\section{METODE PENELITIAN}

\section{Pendekatan dan Jenis Penelitian}

Upaya mencari dan mengumpulkan data yang akurat, peneliti menggunakan penelitian kualitatif. Penelitian kualitatif yaitu mencari makna, pemahaman, pengertian, verstehen tentang suatu fenomena, kejadian, maupun kehidupan manusia dengan terlibat langsung dan/atau tidak langsung dalam setting yang diteliti, kontektual, dan menyeluruh. Peneliti bukan mengumpulkan data sekali jadi atau sekaligus dan kemudian mengolahnya, melainkan tahap demi tahap dan makna disimpulkan selama proses berlangsung dari awal sampai akhir kegiatan, bersifat naratif, dan holistik. Peneliti dalam penelitian kualitatif mencoba mengerti makna kejadian atau peristiwa dengan mencoba berinteraksi dengan orang-orang dalam situasi/fenomena tersebut. ${ }^{10}$ Adapun model penelitian yang dilakukan yaitu deskriptif. Langkah ini peneliti harus mendeskripsikan suatu obyek, fenomena atau

${ }^{10}$ Yusuf, A. M. (2014). Metode Penelitian Kuantitatif, Kualitatif, dan Penelitian Gabungan. Kencana. Hlm. 328 
setting sosial yang akan dituangkan dalam tulisan yang bersifat naratif. Artinya dalam penulisan data dan fakta yang dihimpun berbentuk kata atau gambar dari pada angka. Dalam hal ini peneliti memfokuskan penelitian mengenai masalah literasi kitab kuning pada santri Pondok Pesantren AlMuhsinin Koto Petai Kabupaten Kerinci.

2. Subyek PenelitianSubjek penelitian merujuk pada orang/individu yaitu masyarakat atau kelompok. Subjek penelitian atau informan adalah orang yang diminta untuk memberikan keterangan atau informasi tentang suatu fakta atau pendapat. Jadi subjek penelitian itu merupakan suatu sumber informasi yang digali untuk mengungkapkan fakta-fakta di lapangan yang dibutuhkan peneliti dan sesuai dengan judul atau tema yang diteliti. Dalam penelitian ini, peneliti menggunakan teknik Purposive Sampling, yaitu pemilihan subjek atau sampel yang sudah diketahui karakter dan ciri-cirinya, dan dianggap dapat memberikan informasi yang dibutuhkan oleh peneliti sesuai dengan kapasitas kompetensinya. Subjek penelitian di sini adalah Kepala Desa yakni untuk mempermudah peneliti dalam mendapatkan data, dokumentasi mengenai topik penelitian, kemudian kepala/pimpinan Pondok Pesantren Al-Muhsinin yaitu untuk mempermudah peneliti dalam mendapatkan data, dokumen mengenai topik penelitian, kemudian subjek penelitian yang lebih khusus yaitu santri kelas 11 Pondok Pesantren Al-muhsinin Koto Petai yaitu untuk mendapatkan data agar terjawabnya rumusan masalah pada penelitian ini.

\section{Teknik Pengumpulan Data}

a. Observasi

Observasi adalah metode pengumpulan data yang dilakukan peneliti untuk mengamati atau mencatat suatu peristiwa dengan penyaksian langsungnya. Dan biasanya penelitian dapat sebagai partisipan atau observasi dalam menyelesaikan atau mengamati suatu objek peristiwa yang diteliti. ${ }^{11}$

\footnotetext{
${ }^{11}$ Rosady Ruslan. (2006). metode penelitian. Hlm. 219
} 
b. Wawancara

Wawancara adalah percakapan dengan maksud tertentu. Percakapan itu dilakukan oleh dua pihak, yaitu pewawancara (interviewer) yang mengajukan pertanyaan dan terwawancara (interviewer) yang memberikan jawaban atas pertanyaan itu. ${ }^{12}$

c. Dokumentasi

Dokumentasi merupakan catatan peristiwa yang sudah berlalu. Dokumen bisa berbentuk tulisan gambar atau karya-karya monumental dari seseorang, dokumen yang berbentuk tulisan misalnya catatan harian, sejarah kehidupan, cerita, biografi, peraturan, kebijaksanaankebijaksanaan dan dokumen berbentuk gambar misalnya foto, gambar hidup, sketsa dan lain-lain. ${ }^{13}$

\section{Teknik Analisis Data}

Ada tiga jenis kegiatan dalam analisis data, yaitu Reduksi Data, Penyajian Data, dan Penarikan Kesimpulan

\section{PEMBAHASAN}

1. Kemampuan Santri Pondok Pesantren Al-Muhsinin Desa Koto Petai dalam Mengakses Informasi Kitab Kuning

Dalam mengakses informasi terdapat dua sub komponen yaitu mendefinisikan kebutuhan dan penelusuran informasi. Untuk mendefinisikan kebutuhan informasi yang akan dicari setiap individu diharuskan teliti untuk menemukan dan menggali informasi yang akan

\footnotetext{
${ }^{12}$ Lexy J. Moleog (2017). Metodelogi Penelitian Kualitatif. Bandung: Remaja Rosdakarya.
} HIm 186.

${ }^{13}$ Sugiyono (2018). Metode Penelitian Kualitatif. Bandung: Alfabeta. Hlm 124. 
diperoleh agar tidak terjadinya kekeliruan. Dalam pencarian informasi bisa dimulai dari mengakses informasi melalui berbagai media, baik media cetak maupun media elektronik, komunikasi langsung dan komunikasi tidak langsung yang menggunakan isyarat atau simbol-simbol tertentu. Kemampuan santri Pondok Pesantren Al-Muhsinin Desa Koto Petai dalam Mengakses Informasi Kitab Kuning cukup baik, karena informasi yang terkandung di dalam kitab kuning merupakan informasi yang sangat penting dan berguna bagi kehidupan sehari-hari. Dalam mendefinisikan informasi pemahaman informan tentang kitab kuning cukup beragam namun memiliki inti dan hasil yang sama. Untuk menemukan informasi yang terkandung di dalam kitab kuning kita perlu melakukan sesuatu agar dapat menemukan informasi yang dibutuhkan. Dalam penulusuran informasi Masing-masing orang mempunyai cara tersendiri untuk menelusuri atau mengakses informasi yang dibutuhkan, informan mengakses informasi melalui diskusi bersama guru atau ustadz dan juga teman-teman. Selanjutnya informasi yang didapat kemudian dipilah dan dipilih untuk diterapkan dalam kehidupan sehari-hari.

\section{Kemampuan Santri Pondok Pesantren Al-Muhsinin Desa Koto Petai dalam Mengevaluasi Informasi Kitab Kuning}

Dalam mengevaluasi informasi terdapat dua sub komponen yaitu penilaian informasi dan pengaturan informasi. Informasi merupakan salah satu hal yang sangat penting untuk diketahui karna semua orang membutuhkan informasi. Informasi bisa kita katakan akurat apabila dapat memberikan informasi sesuai dengan fakta yang ada.. Kemampuan santri Pondok Pesantren Al-Muhsinin Desa Koto Petai dalam Mengevaluasi Informasi Kitab Kuning cukup baik, karena dalam penilaian informasi segala informasi yang diperoleh setiap individu tentunya mempunyai manfaat tersendiri bagi setiap individu, menurut informan kegiatan mempelajari kitab kuning ini merupakan kegiatan yang sangat bermanfaat dan dan memberikan ilmu tentang keagamaan yang penting dan berguna 
untuk kehidupan sehari-hari. Dalam pengaturan informasi Untuk mendapatkan informasi yang jelas setiap orang mempunyai versi yang bebeda-beda jenisnya, ada yang memilih dan memilah terlebih dahulu informasinya dan ada juga yang langsung menggunakan informasinya. Tergantung dari setiap orang bagaimana cara mendapatkan informasinya,

\section{Kemampuan Santri Pondok Pesantren Al-Muhsinin Desa Koto Petai dalam Menggunakan Informasi Kitab Kuning}

Dalam menggunakan informasi terdapat dua sub komponen yaitu menggunakan informasi dan mengkomunikasikan informasi. Menggunakan informasi bekaitanan dengan bagaimana cara untuk mengkomunikasikan, menyajikan, dan menggunakan informasi dengan baik dan juga mampu untuk mengaplikasikan informasi yang telah ditemukan. Penerapan atau penggunaan informasi dilakukan apabila informasi telah ditemukan dan dievaluasi dalam memilah dan memilih informasi yang nantinya akan memberikan manfaat bagi masyarakat. Informasi yang bermanfaat yaitu informasi yang apabila di sebarkan dan mampu mengkomunikasikannya dengan baik, maka akan berdampak baik pula bagi orang lainnya. Berkomunikasi atau mengkomunikasikan, merupakan cara untuk berbagi informasi kepada orang atau teman dengan begitu apa yang di sampaikan dan apa yang diinginkan terpenuhi dalam artian terwujud. Kemampuan Santri Pondok Pesantren Al-Muhsinin Desa Koto Petai dalam Menggunakan Informasi Kitab Kuning kurang baik karena dalam menggunakan atau mengaplikasikan informasi yang mereka dapatkan para informan belum sepenuhnya menerapkan, menggunakan atau mengaplikasikan informasi yang mereka peroleh. Dalam mengkomunikasikan informasi para informan banyak yang tidak memahami cara mengkomunikasikan informasi yang baik kepada pihak lain sehingga informasi yang mereka dapatkan jarang sekali untuk mereka komunikasikan kepada pihak lain. 


\section{E. KESIMPULAN DAN SARAN}

1. Kesimpulan

Berdasarkan pembahasan di atas dapat ditarik simpulan bahwa kemampuan santri pondok pesantren Al-Muhsinin desa koto petai dalam mengakses informasi kitab kuning cukup baik, ini dapat dilihat dari informasi yang didapat dari berdiskusi besama guru dan ustadz dan juga bersama teman-teman selanjutnya informasi yang didapat ini kemudian dipilah dan dipilih untuk bisa diterapkan dalam kehidupan sehari-hari. Selanjutnya kemampuan santri pondok pesantren Al-muhsinin desa koto petai dalam mengevaluasi informasi kitab kuning cukup baik, ini dapat dilihat bahwa untuk mendapatkan informasi yang jelas setiap orang mempunyai versi yang bebeda-beda jenisnya, ada yang memilih dan memilah terlebih dahulu informasinya dan ada juga yang langsung menggunakan informasinya. Tergantung dari setiap orang bagaimana cara mendapatkan informasinya. Kemampuan santri pondok pesantren Almuhsinin koto petai dalam menggunakan informasi kitab kuning kurang baik. Hal ini dapat dilihat bahwa dalam menggunakan informasi yang di peroleh informan belum menerapkan atau mengaplikasikannya dan dalam mengkomunikasikan informasi kepada pihak lain informan juga jarang sekali untuk mengkomunikasikan informasi yang diketahuinya kepada pihak lain.

2. Saran

Adapun saran atau rekomendasi dari penulis terkait dengan literasi kitab kuning oleh santri pondok pesantren Al-Muhsinin desa koto petai adalah sebagai berikut: 
a. Terkait akses terhadap sumber informasi diharapkan para santri menggunakan sumber informasi lain yang lebih variative dan beraneka ragam. Informasi diperoleh tidak hanya bersumber pada guru atau ustaz saja. santri diharapkan memiliki inisiatif untuk melakukan akses terhadap sumber informasi lainnya seperti menggunakan internet dan lain sebagainya.

b. informasi yang diperoleh dengan mempelajari kitab kuning sangat bermanfaat bagi para santri terutama dalam hal mendalami ilmu keagamaan. Nilai informasi bersifat positif yang terkandung didalam isi kitab kuning yang dipelajari oleh para santri hendaknya dijadikan sebagai pedoman dan tuntunan hidup sehari-hari.

c. Kesulitan yang dialami oleh para santri dalam mengkomunikasikan kembali informasi yang mereka peroleh dari mempelajari kitab kuning kepada orang lain perlu mendapatkan perhatian khusus. Bisa dengan melakukan kajian rutin mengenai pembelajaran kitab kuning bagi warga yang berada di sekitar pondok pesantren tersebut.

\section{F. Daftar Pustaka}

Kharizmi, M. (2015). Kesulitan siswa sekolah dasar dalam meningkatkan kemampuan literasi. Jupendas. Vol. 2, No. 2. http://jfkip.umuslim.ac.id/index.php/jupendas/article/view/233.

Malawi, I. (2017). Pembelajaran Literasi Berbasis Sastra Lokal. Jawa Timur: Media Grafika.

Abidin, Y. (2018). Pembelajaran Literasi. Jakarta: Bumi Aksara.

Hartono. (2016). Manajemen Perpustakaan Sekolah. Yogyakarta: Ar-Ruzz Media.

Hancock, Vicky E. Information Literacy For Lifelong Learning, 1993 .http://ericae.net/edo/ED358870.htm.

Pattah, S. H. (2014). Literasi Informasi, Peningkatan Kompetensi Informasi dalam Proses Pembelajaran. Al-Hikma. 
Mentari , A. (2014). Literasi Informasi Politik Pada Masyarakat di Tempat Pemungutan Suara Desa Simpang Sungai Duren Kabupaten Muaro Jambi. Skripsi IAIN sulthan thaha saifuddin Jambi.

(katz dikutip oleh yusup, 2009:205) http://www.researchgate.net/publication/331096122_PERILAKU_PEN CARI_INFORMASI_INFORMATION_SEEKINGBEHAVIOR_GURU BESAR_IAIN_ANTASARI_BANJARMASIN.

Lau, Jesus. Guiddelines on Information Literacy for lifelong Learning. Veracruz: IFLA. 2006.

Tim Penyusun Buku Pedoman Skripsi. 2018. Pedoman Penulisan Proposal dan Skripsi Fakultas Adab dan Humaniora. Jambi:UIN STS JAMBI.

Lexy J. Moleong (2017). Metodelogi Penelitian Kualitatif. Bandung: Remaja Rosdakarya. 